\title{
Piotr Sadowski*
}

\section{THE EUROPEAN COURT OF HUMAN RIGHTS (ECTHR) CASE OF S.K. V. RUSSIA, JUDGMENT OF 14 FEBRUARY 2017}

\begin{abstract}
An increasing inflow of immigrants exposes European countries to unprecedented challenges in ensuring the efficiency of human rights. Rising xenophobia provokes states to narrowly interpret the 1951 Geneva Convention on the Status of Refugees. Among others, a rigorous application of the concept of an individualised fear of persecution excludes the general consequences of war. References to the safe parts of countries of origin are used to justify decisions on the non-granting of international protection. This analysis of the European Court of Human Rights judgment of 14 February 2017 in S.K. v. Russia (Appl. no. 52722/15) refers to all of above-mentioned themes. Moreover, the research compares the Council of Europe standards and Russian legislation and practice with those of the EU.
\end{abstract}

\section{Keywords}

refugees sur place - internally displaced persons (IDPS) - individualized risk of persecution - detention - a general situation of violence

* Dr Piotr Sadowski, Assistant in the Human Rights Department at the Faculty of Law and Administration of Nicolaus Copernicus University in Torun with a public administration background (participant in the EU Council Working Groups and in the European Commission Expert Meetings, coordinator, and an expert in international projects), e-mail: psadowski@umk.pl. 


\section{INTRODUCTION}

The number of immigrants, including people seeking international protection, who are approaching Europe, is the highest since the end of World War II ${ }^{1}$. According to Eurostat, "the 28 Member States of the European Union (EU) granted protection status to 710,400 asylum seekers in 2016, more than double the number of 2015. (...) The number of decisions granting protection status to Syrians has more than doubled since 2015: they were the largest group granted protection status in nineteen Member States in 2016." 2 .

However, Russia is also affected by the migration crisis. According to the most recent data, in 2016 Russia hosted 1,300 refugees from Syria (out of 272,000 recognised refugees who were present in Russia) ${ }^{3}$ and registered 22,000 new arrivals of refugees ${ }^{4}$. Furthermore, 3,039 applications were still pending 5 and 21,995 persons were granted complementary protection status in Russia (in a format of temporary asylum) and 39 persons received refugee status ${ }^{6}$. Nevertheless, a decreasing trend in new arrivals can be noticed - the highest inflow occurred in 2014 and it declined by half in $2015^{7}$.

In times of unprecedented arrivals of immigrants, countries face increasing challenges as regards ensuring human rights in accordance

${ }^{1}$ L. DePillis, K. Saluja, D. Lu, A visual guide to 75 years of major refugee crises around the world, "Washington Post" of 21.12.2015, available at: https:/ / www.washingtonpost. com/graphics/world/historical-migrant-crisis/ [last accessed: 9.6.2017].

${ }^{2}$ Eurostat, Asylum decisions in the EU. EU Member States granted protection to more than 700000 asylum seekers in 2016. Over half of the beneficiaries were Syrians., Eurostat news release 2017, no. 17, available at: http:/ / ec.europa.eu/ eurostat/documents/2995521/8001715/326042017-AP-EN.pdf/05e315db-1fe3-49d1-94ff-06f7e995580e [last accessed: 23.5.2017], p. 1.

${ }^{3}$ UNHCR, Global Focus 2016 Year-End report. Operation: Russian Federation, available at: http://reporting.unhcr.org/sites/default/files/pdfsummaries/GR2016RussianFederation-eng.pdf [last accessed on: 6.10.2017], p. 4.

${ }^{4}$ UNHCR, Global Trends Forced Displacement in 2016, UNHCR 2017, available at: http://www.unhcr.org/statistics/unhcrstats/5943e8a34/global-trends-forceddisplacement-2016.html?query=Russia [last accessed on: 6.10.2017], p. 19.

${ }^{5}$ Ibid., p. 62.

${ }^{6}$ Ibid., Table 10.

7 Ibid., p. 41. 
with the 1950 European Convention on Human Rights and Fundamental Freedoms (the 1950 Convention) ${ }^{8}$ and the 1951 Geneva Convention on the Status of Refugees (the 1951 Geneva Convention) ${ }^{9}$, among others. In that respect it should be noted that "In the Russian Federation, difficulties accessing asylum procedures were reported in the first half of 2017"10. The Russian government has already started actions aiming at improving asylum processing claims, among other matters ${ }^{11}$. Bearing in mind that in 2015 there were 598,617 foreigners living in Russia ${ }^{12}$, it can be assumed that Russia will still be considered as an important transit and destination country by immigrants and asylum seekers. Therefore, reflections are timely on the material and procedural aspects of ensuring respect for rights which are guaranteed by Article 2 and 3 of the 1950 Convention.

Themes covered by this research serve as a ground for a comparison of the standards which are provided by the 1951 Geneva Convention, the 1950 Convention, Russian legislation, and the European Union laws on asylum. Inclusion of the EU norms is justified by the fact that this regional institution considers its standards as equal or higher than those established by the Council of Europe ${ }^{13}$.

Thus, I firmly believe that the European Court of Human Rights (the ECtHR) judgment of 14 February 2017 in the S.K. v. Russia ${ }^{14}$ case in which the Court reiterated and clarified the importance of an individual assessment of:

8 Available at: http://www.echr.coe.int/Documents/Convention_ENG.pdf [last accessed: 25.2.2017].

${ }_{9}$ Available at: http://www.unhcr.org/3b66c2aa10 [last accessed: 6.5.2017]. It was amended by the 1967 Protocol Relating to the Status of Refugees.

${ }^{10}$ Executive Committee of the High Commissioner's Programme, Regional update Europe. Prepared for Executive Committee of the High Commissioner's Programme Sixty-eighth session in Geneva (2-6 October 2017), 22 September 2017, available at: http:/ / www.unhcr. org/excom/orginfo/59c8fd827/europe-regional-update.html?query=Russia [last accessed on: 6.10.2017], p. 2.

11 Ibid.

12 Federal State Statistics Service (Rosstat), Международная Миграция [International Migration], Москва 8.7.2016. The document does not indicate the methodology of collecting and analysing the above-mentioned data.

${ }^{13}$ See Article 52(3) of the 2000 Charter of Fundamental Rights of the European Union (OJ EC C 364/1 of 18.12.2000).

${ }_{14}$ Appl. no. 52722/15. 
- "continuing hostilities in Syria" (an issue of refugees sur place),

- a continuous prolongation of detention of migrants who have no prospects of being returned, and

- an internal flight alternative.

is interesting from an academic as well as from a practical point of view.

\section{THE FACTS OF THE CASE}

In October 2011, S.K. (the applicant) came to Russia from Syria. He did not leave the destination country, although the validity of his visa expired ${ }^{15}$. On the contrary, he developed family ties with a Russian citizen to whom he got married (in April 2014) and fathered a child (in November 2013).

In February 2013, he was found guilty of committing the administrative offence of unlawful employment in Russia. Two years later, the Court in Makhachkala (Dagestan Republic of Russia) imposed a fine and ordered a penalty of forcible removal of the applicant from Russia. To secure the enforcement of that decision, the Court placed S.K. in a special detention centre for foreigners. That decision was appealed against by S.K. in February 2015 by referring to his family ties with Russian citizens.

In March 2015, the Supreme Court of the Dagestan Republic upheld the decision. It underlined that "[the applicant's] prolonged violation of the migration legislation since October 2012 amounts to abuse of Russia's hospitality and thus should be treated as a breach of the receiving country's interests" ${ }^{16}$

Nevertheless, the administrative removal decision was not initiated. This was a result of the fact that S.K. applied for temporary asylum. He claimed that upon his return to Syria he would be drafted to the government's active military service. Therefore, according to the applicant, his life and physical integrity would be put into danger.

In August 2015, the local migration authority decided not to grant temporary asylum to S.K. This decision was upheld in September 2015 by

15 According to F. Düvell this is the most common path leading to an illegal stay. F. Düvell, The Pathways in and out of Irregular Migration in the EU: A Comparative Analysis, "European Journal of Migration and Law" 2011, vol. 13, p. 247.

${ }^{16}$ Quoted after the S.K., par. 12. 
the Russian Federal Migration Service. It underlined that "The Ministry of Foreign Affairs points out that Syrian nationals who return to their homeland or who are deported or expelled there may arrive in Damascus and then proceed to other regions that are controlled by governmental forces" 17 .

The applicant did not agree with that decision and asked Leninskiy District Court of Makhachkala to suspend his removal. He referred to the fact that he sought a judicial review of the refusal on granting him a temporary protection. In December 2015, the Basmannyy District Court of Moscow refused to grant him temporary asylum. The court claimed that temporary asylum could be granted only in case of:

"a grave medical condition for which the foreigner will not receive the requisite medical care in the country of nationality, thus putting his or her life at risk; a real threat to his or her life or liberty on account of hunger, epidemics, emergency situations of environmental or industrial origin or on account of an internal or international conflict that encompasses the entire territory of the state of nationality; a real threat of being subjected to torture or another cruel, inhuman, or degrading treatment or punishment in the country of nationality." ${ }^{18}$.

In June 2016, the Moscow City Court dismissed S.K.'s appeal. It underlined that the applicant had not met the prerequisites specified in the domestic legislation on refugees, as he had not delivered specific facts to prove an exposure to persecution which he would face after being returned to Syria. Finally, the Court "noted" that the applicant asked for temporary protection after 4 years of staying in Russia ${ }^{19}$.

\section{SCOPE OF the Claim}

The application was submitted on 12 November 2015. The applicant (a Syrian national, S.K.) based his request by referring to:

17 Quoted after Ibid., par. 18.

${ }_{18}$ Quoted after Ibid., par. 21.

${ }^{19}$ Quoted after Ibid., par. 22. 
- Article 2 and 3 of the 1950 Convention - claiming that his administrative removal from Russia to Syria would expose him to a serious risk of ill-treatment due to the general situation of violence in Syria;

- Article 5 - claiming that the continuing prolongation of his administrative detention was arbitrary and unnecessary, because his removal to Syria could not be executed;

- Article 8 and 13 - claiming that his removal was disproportionate, as his family ties with Russian citizens (his wife and their child) would be breached.

\section{KEY THEMES IN THE ECTHR JUDGMENT OF S.K. V. RUSSIA}

\section{RISK/REFUGEES SUR PLACE}

Article 1A of the 1951 Geneva Convention provides a definition of a term "a refugee". However, it does not specify the moment in time when one becomes a refugee. This may not be at stake when an individual leaves his/her country of origin after being persecuted. However, it will have an unquestionable impact on people who are in need of international protection owing to actions which occurred after their departure ${ }^{20}$, even though their decision to leave had been taken "without fear [of persecution, but] for some other purpose, for example, a holiday or study" 21 .

Looking at the universal system of protection of human rights, bearing in mind a duty imposed on the signatories to the 1951 Geneva Convention

${ }^{20}$ S. Da Lomba, The EU Qualification Directive and Refugees Sur Place [in:] F.A.N.J. Goudappel, H.S. Raulusu (eds.), The future of asylum in the European Union. Problems, proposals and human rights, The Hague 2011, pp. 43-64.

${ }^{21}$ G. Clayton, Textbook on Immigration and Asylum Law, 7th ed., Oxford 2016, p. 448. Similar examples are provided in: A. Zimmermann, C. Mahler, Article 1A, para. 21951 Convention [in:] A. Zimmermann, J. Dörschner, F. Machts, The 1951 Convention Relating to the Status of Refugees and Its 1967 Protocol: A Commentary, Oxford 2011, p. 329. Compare with: G. S. Goodwin-Gill, J. McAdam, The Refugee in International Law, Oxford/New York 2007, p. 63. 
to cooperate with the UNHCR ${ }^{22}$, the UNHCR "Handbook" is a very useful support as regards the concept of refugees sur place ${ }^{23}$. Even though it is "just" a soft-law instrument ${ }^{24}$, it has an uncontested influence on the case law of national and international courts ${ }^{25}$.

In the above-cited document, the UNHCR claims that a person is ipso facto a refugee when s/he meets the criteria outlined in the 1951 Geneva Convention. Thus, a formal decision taken by authorities to grant refugee status confirms (recognises) that an individual has fulfilled preconditions specified in that Convention. Therefore, the UNHCR opted for a declaratory view ${ }^{26}$. Scholars add that an opposite (constitutivist) view is "at odds with the [1950] Refugee Convention" 27.

A risk sur place may be a consequence of:

- a changing situation in the country of origin or

- activities undertaken by an individual after leaving the country of origin ${ }^{28}$.

${ }^{22}$ Article 35(1) of the 1951 Geneva Convention. More in: B. Gronowska, Instytucjonalne gwarancje ochrony praw człowieka [Institutional guarantees of human rights protection] [in:] B. Gronowska, T. Jasudowicz, M. Balcerzak, M. Lubiszewski, R. Mizerski, Prawa człowieka i ich ochrona, Torun 2010, p. 134.

${ }^{23}$ UN High Commissioner for Refugees, Handbook and Guidelines on Procedures and Criteria for Determining Refugee Status under the 1951 Convention and the 1967 Protocol Relating to the Status of Refugees, December 2011, HCR/1P/4/ENG/REV. 3, available at: http:/ / www. refworld.org/docid/4f33c8d92.html [last accessed: 18.2.2017], point 28.

${ }^{24} \mathrm{~J}$. Chlebny, Postępowanie w sprawie o nadanie status uchodźcy [A Refugee Status Determination Procedure], Warszawa 2011, p. 37. Its role was contested by: H. Storey, The Internal Flight Alternative Test: The Jurisprudence Re-examined, "International Journal of Refugee Law" 1998, vol. 10, issue 3, p. 507.

${ }_{25}$ Among others, the ECtHR refers to the definition of refugees sur place, which can be found in the UNHCR's "Handbook" when Strasbourg judges consider non-refoulement claims grounded on Article 3 of the 1950 Convention.

${ }^{26}$ See also: C. Costello, E. Hancox, The Recast Asylum Procedure Directive 2013/32/EU: Caught between the Stereotypes of the Abusive Asylum-Seeker and the Vulnerable Refugee [in:] V. Chetail, P. De Bruycker, F. Maiani (eds.), Reforming the Common European Asylum System: The New European Refugee Law, Leiden/Boston 2016, p. 379.

${ }^{27}$ H. Battjes, European Asylum Law and International Law, Leiden/Boston 2006, p. 455;

C. Costello, The Human Rights of Migrants and Refugees in European Law, Oxford 2016, p. 64;

F. Cherubini, Asylum Law in the European Union, New York 2015, pp. 96-97.

28 S. Da Lomba, supra note 20, pp. 46-47, A. Zimmermann, C. Mahler, supra note 21, p. 329-334, S. Velluti, Reforming the Common European Asylum System - Legislative 
The first group of risks is "objective" risks sur place, whereas the second is "subjective" risk sur place ${ }^{29}$. According to A. Zimmermann, J. Dörschner, and F. Machts the majority of asylum seekers refer to the former risks ${ }^{30}$. S. Velluti underlines that even though in principle, sur place claims must be assessed on the same basis as all other claims for refugee status, a reluctance in that regard can be noticed ${ }^{31}$.

According to the UNHCR "a coup d'état, change of government, significant change in government policy, outbreak or escalation or armed conflict, or the disclosure of the names of asylum applicants to officials in the country of origin" ${ }^{32}$, illustrate a changing situation in the country of origin. H. Battjes adds that also a diplomat who stays abroad can claim a risk sur place if - for political reasons - an arrest warrant was issued in his case in his country of origin ${ }^{33}$.

Activities undertaken by an individual after leaving the country of origin can be of a different nature. Scholars claim that refugees sur place frequently refer to their conversion to a religion which is not tolerated by the authorities in the country of origin ${ }^{34}$, their political involvement ${ }^{35}$

developments and judicial activism of the European Courts, London 2014, pp. 50-51. On a more reluctant approach to a risk sur place which is aresult of activities undertaken by an individual in: S. Da Lomba, supra note 20, p. 49.

29 A. Zimmermann, C. Mahler, supra note 21, p. 329.

${ }^{30}$ Ibid., p. 329.

31 S. Velluti, supra note 28, p. 51.

${ }^{32} \mathrm{UNHCR}$, Refugee Status Determination. Identifying who is a refugee. Self-study module 2, Geneva 2005, available at: http:/ / www.unhcr.org/cgi-bin/texis/vtx/search?page=search \&skip $=18 \&$ docid $=43144$ dc52\&query $=$ definition $\% 20$ of $\% 20 \mathrm{a} \%$ 20refugee [last accessed: 6.10.2017], p. 44.

${ }^{33}$ H. Battjes, Piecemeal Engineering: The Recast of the Rules on Qualification for International Protection [in:] V. Chetail, P. De Bruycker, F. Maiani (eds.), Reforming the Common European Asylum System: The New European Refugee Law, Leiden/Boston 2016, pp. 221-222. Recalling the fact that an arrest warrant can be valid within the while territory, it should also be stressed that it may also be invoked by asylum seekers who do not agree with an application of an internal flight alternative.

${ }^{34}$ A. Zimmermann, C. Mahler, supra note 21, p. 329; E. Hamdan, The Principle of Non-Refoulement under the ECHR and the UN Convention against Torture and Other Cruel, Inhuman, or Degrading Treatment or Punishment, Leiden/Boston 2016, pp. 260-261.

35 See e.g. G. Clayton, supra note 21, p. 448. 
and a likelihood of penalisation of activities taken by them in the country of destination ${ }^{36}$.

The ECtHR has already referred to the situation of a convert who was expected to return to his country of origin. In the judgment of 23 March 2016 in F.G. v. Sweden ${ }^{37}$ the Court found that the applicant, who was baptised in Sweden after leaving Iran, decided "to keep his faith a private matter" 38 , but he provided status examination authorities with some indications that he based his asylum claim, among others, on a risk of ill-treatment which he would be exposed to after returning to Iran ${ }^{39}$. Therefore, according to the Court, Swedish authorities had to ensure ex nunc assessment on that ground and consider a general situation in Iran and the particular circumstances of the applicant's situation ${ }^{40}$.

Considering the political involvement of refugees sur place, G. Clayton underlines that it must be of a genuine political interest ${ }^{41}$. Therefore, it cannot be of an opportunistic nature, so it cannot be motivated mainly or solely by a wish to obtain refugee status in a country of destination ${ }^{42}$.

S. Da Lomba ${ }^{43}$ and S. Velutti ${ }^{44}$ claim that a changing situation in the country of origin is more favourably looked at by national authorities than activities taken by an individual after leaving the country of origin as the later "are suspected of being manufactured" 45 . H. Battjest argues that "Continuation of convictions is sufficient, but not necessarily required for recognition of a claim under the Refugee Convention. As to Article $3 \mathrm{ECHR}(. .$.$) the intentions or purposes of a third country national are$

${ }^{36}$ Those concepts are, however, questioned by national courts. More in: J.C. Hathaway, M. Foster, The Law of Refugee Status, Cambridge 2014, pp. 78.

37 Appl. no. 43611/11.

38 Ibid., para. 89.

39 Ibid., para. 157.

${ }^{40}$ Ibid.

${ }^{41}$ G. Clayton, supra note 21, p. 448. She recalls the judgment of England and Wales Court of Appeal - Civil Division judgment of Ahmed (Iftikhar) v. Secretary of State for the Home Department [2000] INLR 1. The ECtHR referred to a genuine interest also in cases concerning religious activity taken in the country of destination. F.G. v. Sweden, para. 123.

${ }^{42}$ G. Clayton, supra note 21 p. 448.

43 S. Da Lomba, supra note 20, p. 43-64.

${ }^{44}$ S. Velluti, supra note 28 , pp. 50-51.

${ }^{45}$ Ibid.; S. Da Lomba, supra note 20, p. 43-64. 
immaterial for state responsibility in expulsion cases." ${ }^{46}$. G.S. GoodwinGill and J. McAdam add that "some European doctrine attaches particular importance to political activities sur place being a continuation of activities begun in the country of origin, this may be intended to go to the question on credibility and 'well-foundedness', as the ordinary meaning of article 1A(2) [of the 1951 Geneva Convention] would imply"47. This notion, which was developed by German jurisprudence, is now widely applied ${ }^{48}$. Its popularity may be justified by the fact that the majority of claims submitted by refugees sur place are grounded on the political involvement of applicants ${ }^{49}$.

Political involvement can take different forms and it may include public (in media or in the Internet) expression of political views (e.g. criticizing a government of a country of origin). However, those activities must be sufficiently extensive to justify a risk sur place ${ }^{50}$.

Finally, some countries punish an unauthorised departure and/or submission of an application for asylum ${ }^{51}$. Regarding the former, ECRE convincingly stressed that "A political conviction may be attributed to the claimant by the persecutor, notwithstanding a lack of real political conviction on the part of the refugee claimant if, for example, the claimant has simply decided to extend a period abroad or did not return in time at the summons of a new government." 52 . Regarding the later, in the judgment of the ECtHR of 26 July 2005 in N. v. Finland ${ }^{53}$ the Court underlined that the applicant may be exposed to persecution in the

${ }^{46}$ H. Battjes, European Asylum Law and International Law, Leiden/Boston 2006, p. 261.

47 G.S. Goodwin-Gill, J. McAdam, supra note 21, p. 88.

48 A. Zimmermann, C. Mahler, supra note 21, p. 334.

${ }^{49}$ Ibid., p. 330.

${ }^{50}$ They will be considered as insufficient if he applicant would not be a high-profile activist or political opponent. Cf. F.G. v. Sweden, paras. 88 and 141. By contrast cf. S.F. and Others v. Sweden, judgment of 15.5.2012, appl. no. 52077/10, paras. 62-61.

51 A. Zimmermann, C. Mahler, supra note 21, p. 330. Those concepts are, however, questioned by national courts. More in: J.C. Hathaway, M. Foster, supra note 36, pp. 78.

${ }^{52}$ ECRE, Position On The Interpretation Of Article 1 Of The Refugee Convention - September 2000, available at: https:/ / www.ecre.org/wp-content/uploads/2016/07/Position-on-theInterpretation-of-Article-1-of-the-Refugee-Convention_September-2000.pdf [last accessed on: 7.10.2017], point 40 .

${ }^{53}$ Appl. no. 38885/02. 
Democratic Republic of Congo, because media commented widely on the asylum claim which he submitted in Finland ${ }^{54}$.

A risk of persecution arising in the country of origin may also be associated with criminal proceedings against an immigrant which took place in a country of destination. It may also extend to persons who were not found guilty ${ }^{55}$.

Comments devoted to the moment of time when a person becomes a refugee are important, as the situation in a country of origin may change rapidly and develop quickly (from local protests to an armed conflict). Therefore, a decision cannot refer to past events only. Instead, authorities must make an ex nunc assessment of the facts in asylum cases ${ }^{56}$ and an evaluation of a situation in the country of origin should be based on the most recent facts. Thus, the assessment should take into account data which are available at the moment of finalisation of an administrative procedure.

Certainly, the same rules apply in the case of stateless migrants who are expected to be returned to a country of their "habitual residence". This was confirmed, among others, in the ECtHR judgment of 15 October 2015 in L.M. and Others v. Russia ${ }^{57}$, where the applicant was a stateless Palestinian with a habitual residence in Syria.

Article 5 of the EU Qualification Directive (recast) ${ }^{58}$ provides additional guidelines concerning the extent of data which should be taken into account in a refugee status determination procedure. It also specifies that

${ }^{54}$ Strasbourg judges underlined that "It is relevant in this connection that the applicant himself does not appear to have played any active role in making his asylum case known to the public and, in particular, to other DRC nationals currently in Finland". N. v. Finland, para. 165.

${ }^{55}$ Cf. A. v. the Netherlands, judgment of 20.7.2010, appl. no. 4900/06. An applicant was accused of involvement in a terrorist organisation. His trial was widely commented on in the media. Therefore, he claimed that he would be imprisoned after a return to Libya, although in the Netherlands he was found not guilty.

${ }^{56}$ Cf. J.K. v. Sweden, judgment of 23.8.2016, appl. no. 59166/12, para. 83; Sufi and Elmi v. the United Kingdom, judgment of 28.6.2011, appl. nos. 8319/07 and 11449/07, par. 215; F.G. v. Sweden, para. 115.

57 Appl. no. 40081/14, 40088/14 and 40127/14.

${ }^{58}$ Directive 2011/95/EU of the European Parliament and of the Council of 13 December 2011 on standards for the qualification of third-country nationals or stateless persons as beneficiaries of international protection, for a uniform status for refugees or for persons 
"a well-founded fear of being persecuted or a real risk of suffering serious harm may be based on events which have taken place since the applicant left the country of origin". Nevertheless, the Directive has a binding effect only on the EU Member States. Thus, the ECtHR can feel inspired by its wording, but this will be only a non-binding reflection from other legal regimes. Therefore, making a reference to the Qualification Directive (recast) in the ECtHR's judgments is more likely in the EU Member States' cases as they are bound by the Directive anyway.

Information on a general risk in the country of return has to be contrasted with an individualized risk of persecution which a returnee could face upon arrival in that country. Therefore, decision-making authorities have to confront the applicant's opinions (subjective ones) with information about the country of return (objective data which are delivered e.g. by non-government organizations $)^{59}$. Nevertheless, it is clear that people fleeing because of the climate change cannot claim persecution ${ }^{60}$.

In a refugee status determination procedure the likelihood of persecution does not have to be proved ${ }^{61}$. However, it has to be "reasonably possible", although it does not have to be "conclusively

eligible for subsidiary protection, and for the content of the protection granted (recast), OJ L 337 of 20.12.2011, pp. 9-26. See: S. Da Lomba, supra note 20, pp. 46-47.

59 J. Chlebny, supra note 24, p. 240 and 252. Compare with N.A. v. the United Kingdom, judgment of 17.7.2008, appl. no. 25904/07, paras. 120-122. More on the importance of using reliable information on the country of origin in: G. Gyulai, Country Information in Asylum Procedures. Quality as a Legal Requirement in the EU, Budapest 2011 (Updated version), passim. In the EU it is the European Asylum Support Office which shall organize, promote and coordinate activities relating to information on countries of origin. See Article 4 of the Regulation (EU) No 439/2010 of the European Parliament and of the Council of 19 May 2010 establishing a European Asylum Support Office (OJ L 132 of 29.5.2010, pp. 11-28). Reports of the European Asylum Support Office are available at: https:/ / coi.easo.europa. eu/ [last accessed: 11.7.2017].

${ }^{60}$ M.M. Kenig-Witkowska, Problematyka "uchodźców środowiskowych" w prawie międzynarodowym [The category of 'Environment Refugees' in international law], "Państwo i Prawo" 2013, no. 10, p. 16.

${ }^{61}$ Compare with: M.A. Nowicki, Wokót Konwencji Europejskiej. Komentarz do Europejskiej Konwencji Praw Człowieka [The European Convention. Commentary to the European Convention on Human Rights], 7th ed., Warszawa 2017, p. 419. 
beyond doubt" ${ }^{\prime 2}$. Thus, the UNHCR correctly underlined that a minimum level of likelihood also has to be met as "not all levels of likelihood can be sufficient to give rise to refugee status. A key question is whether the degree of likelihood which has to be shown by the applicant to qualify for refugee status has been established." ${ }^{63}$. Among other matters, authorities should consider previous persecutions faced by the asylum applicant, but results of these findings should not be the main factors influencing a decision, especially when a serious change in the country of origin has taken place ${ }^{64}$.

In the S.K. case the ECtHR found that an issue of a risk sur place was not considered by the Russian administration, even though the situation in Syria had changed since the applicant had left his country of origin ${ }^{65}$. As a consequence, the authorities could not establish whether S.K. was a refugee sur place.

Moreover, the Court specified that "the Contracting States' responsibility (...) in cases of this kind lies in the act of exposing an individual to a real risk of death or ill-treatment ${ }^{\prime \prime 6}$. Thus, an evaluation of a situation in the country of origin has to take into account the most recent data ${ }^{67}$ which are available when authorities make a decision on granting refugee status.

Furthermore, the Court reiterated that removal to the country which was facing "a general situation of violence" ${ }^{68}$ can (in exceptional cases) lead to a violation of Article 3 of the 1950 Convention $^{69}$. This extraordinary approach is therefore based on the concept of a sufficient level of intensity

62 J. Chlebny, supra note 24, p. 43.

${ }^{63}$ UNHCR, Note on Burden and Standard of Proof in Refugee Claims, 16 December 1998, available at: http:/ / www.refworld.org/pdfid/3ae6b3338.pdf [last accessed: 29.6.2017], p. 1.

${ }^{64}$ J. Chlebny, supra note 24, p. 43; Compare with: M.A. Nowicki, supra note 62, p. 420. Cf. J.K. v. Sweden, para. 102.

65 S.K., paras 60-62.

${ }^{66}$ Ibid., par. 58.

${ }^{67}$ On the requirements established in Directive 2013/32/EU of the European Parliament and of the Council of 26 June 2013 on common procedures for granting and withdrawing international protection (OJ L 180, 29.6.2013, pp. 60-95) in: C. Costello, E. Hancox, supra note 26, p. 401.

68 See S.K., par. 55 quoting L.M., par. 119.

${ }_{69}$ This justification is in-line with: UNHCR, „Handbook", point 165. 
of violence in the country of origin. Therefore, "the Court would adopt such an approach only in the most extreme cases of general violence, where there is a real risk of ill-treatment simply because the individual concerned will be exposed to such violence in that country"70. Therefore, as a rule, refugee status would be denied to applicants who refer to general mistreatment, which is associated with war ${ }^{71}$. However, the applicant may prove otherwise ${ }^{72}$.

In the present case an analysis of an "objective" risk sur place was essential as S.K. did not claim any subjective reasons which could justify his well-founded fear of individual persecution. Referring to the general situation in the country of return, the Court recalled reports from its judgment in L.M. ${ }^{73}$. Nevertheless, the ECtHR updated that information (the ECtHR was not satisfied with information provided by the government and the applicant, so it obtained information pro $m o t u)^{74}$ by citing, among others, reports from the UNHCR, and the UK Home Office ${ }^{75}$.

Although the Court found that the applicant had not delivered any updates as regards the situation in Syria, it underlined that it was primarily the government's responsibility to provide evidence that

${ }^{70}$ See S.K., par. 55 quoting L.M., par. 119. This idea can also be found in: F.G. v. Sweden, para. 129; Sufi and Elmi v. the United Kingdom, par. 218; N.A. v. the United Kingdom, para. 115. Compare with Meki Elgafaji and Noor Elgafaji v. Staatssecretaris van Justitie (case C-465/07, judgment of 17.2.2009, ECLI:EU:C:2009:94), para. 39 where that Court specified that "the more the applicant is able to show that he is specifically affected by reason of factors particular to his personal circumstances, the lower the level of indiscriminate violence required for him to be eligible for subsidiary protection". However, an indiscriminate violence may also (but only in exceptional circumstances) justify granting international protection.

${ }^{71}$ See Vilvarajah and others $v$. United Kingdom, judgment of 20.10.1991, appl. nos. $13163 / 87 ; 13164 / 87 ; 13165 / 87 ; 13447 / 87 ; 13448 / 87)$, par. 111 . This view is shared by L. Garlicki, Art. 3. Zakaz tortur [Article 3. Prohibition of torture] [in:] L. Garlicki, P. Hofmański, A. Wróbel (eds.), Konwencja o Ochronie Praw Człowieka i Podstawowych Wolności. Tom I. Komentarz do artykutów 1-18, Warszawa 2010, pp. 132-133. This approach was confirmed in NA, paras. $114-115$.

72 The Court of Justice of the EU confirms that view. Cf. Meki, par. 37. Compare with: H. Battjes, supra note 33, pp. 233.
${ }^{73}$ S.K., par. 46.
${ }^{74}$ Ibid., par. 60.
${ }^{75}$ Ibid., par. 47. 
a return to Syria would not expose S.K. to the risk of ill-treatment ${ }^{76}$. Therefore, the ECtHR reconfirmed that an "objective" risk sur place, which refers to well-known (freely ascertainable) information about a general risk in the country of origin, "entails that the authorities carry out an assessment of that risk of their own motion"77. In the present case, the Court found that the government had failed to meet that requirement.

\section{AN INTERNAL FLIGHT ALTERNATIVE}

In times of immigration crisis, a reference to an internal flight alternative (IPA, also called "internal protection alternative" 78 and "internal relocation alternative" ${ }^{\prime 79}$ ) is an important guide to all the countries of the Council of Europe, including the EU Member States. C. Costello adequately identified that "Notwithstanding its lack of clear foundation in the [1951] Refugee Convention (...), this notion has now been institutionalized in State practice and UNHCR guidelines" ${ }^{\prime 0}$ and the UNHCR's

${ }_{76}$ Ibid., par. 59. More in: C. Costello, E. Hancox, supra note 26, p. 401.

77 F.G. v. Sweden, para. 126. Compare with Hirsi Jamaa and Others v. Italy, judgment of 23.2.2012, appl. no. 27765/09, paras. 131-133 and M.S.S. v. Belgium and Greece, judgment of 21.1.2011, appl. no. 30696/09, para. 366. If the S.K. would claim an individual risk, he would be obliged to prove it.

${ }^{78}$ See e.g. J.C. Hathaway, M. Foster, Internal protection/relocation/flight alternative as an aspect of refugee status determination [in:] E. Feller, V. Türk, F. Nicholson (eds.), Refugee Protection in International Law. UNHCR's Global Consultations on International Protection, Cambridge 2003, p. 357. The differences between the names of this concept are explained in: N. Kelley, Internal Flight/Relocation/Protection Alternative: Is It Reasonable, "International Journal of Refugee Law" 2002, vol. 14, issue 1, p. 5.

${ }^{79}$ See e.g. M. Zard, Towards a Comprehensive Approach to Protecting Refugees and the Internally Displaced [in:] A. Fruma Bayefsky (ed.), Human Rights and Refugees, Internally Displaced Persons and Migrant Workers: Essays in Memory of Joan Fitzpatrick and Arthur Helton, Leiden/Boston 2006, p. 34.

${ }^{80}$ C. Costello, supra note 27, p. 175. As regards the UNHCR she refers to: UNHCR, Guidelines on International Protection: "Internal Flight or Relocation Alternative" within the Context of Article 1A(2) of the 1951 Convention and/or 1967 Protocol relating to the Status of Refugees, Doc. HCR/GIP/03/04 23 of July 2003. An origin of the internal flight alternative (the fact that it was an interpretation of the 1951 Geneva Convention) is also underlined in: L. Aldenhoff, G. Clayton, P. McDonough, Actors of Protection and the Application of the Internal Protection Alternative European Comparative Report, ECRE 2014, available at: 
"Handbook" 81 . This practice was developed ad hoc in the mid-1980s and quickly became commonly applied ${ }^{82}$. However, the concept of security in a part of the country of an immigrant's origin is still questioned in the literature, although those views are rare nowadays ${ }^{83}$.

It is rather commonly agreed that there is "no reason in principle why an asylum seeker's fear of persecution should relate to the whole of his or her country of origin" ${ }^{84}$. This is owing to the fact that even though a return to a place of a migrant's former residence may not be possible, a return to other parts of that country may still be considered. Therefore, an asylum seeker will not meet the prerequisites envisaged in the 1951 Geneva Convention, if in a part of the country of return:

- $\mathrm{s} /$ he will not face persecution and

- the state (or other actors who control the country or the part of the country) is able and willing to ensure the safety of persons staying in its territory ${ }^{85}$.

This approach reflects a subsidiary role of the international refugee law (in the context of the 1951 Geneva Convention) ${ }^{86}$ and international human rights law (in the context of the 1950 Convention). Nevertheless, the Parliamentary Assembly of the Council of Europe argued "that

https:/ / www.ecre.org/wp-content/uploads/2016/07/ECRE-Asylum-Aid-DCR-andHHC_Actors-of-Protection-and-the-Application-of-the-Internal-Protection-Alternative_ July-2014.pdf [last accessed on: 8.10.2017], p. 33.

${ }^{81}$ UN High Commissioner for Refugees, supra note 23, point 91.

82 J.C. Hathaway, International Refugee Law: The Michigan Guidelines on the Internal Protection Alternative, Michigan Journal of International Law 1999, vol. 21, issue 1, p. 132. More on a history of an internal flight alternative in: J.C. Hathaway, M. Foster, supra note 78, p. 359-361 and H. Storey, supra note 24, pp. 499-532.

83 Cf. G. Gilbert, Is Europe Living Up to Its Obligations to Refugees?, European Journal of International Law 2004, vol. 15, no. 5, p. 976; C. Teitgen-Colly, The European Union and Asylum: an Illusion of Protection, "Common Market Law Review" 2006, vol. 43, issue 6, p. 1519.

${ }^{84}$ G.S. Goodwin-Gill, J. McAdam, supra note 21, p. 123.

${ }^{85}$ Compare with: K. Keith, The Difficulties of Internal Flight and Internal Relocation as Frameworks of Analysis, "Georgetown Immigration Law Journal" 2001, vol. 15, p. 439 and (on non-state agents) L. Aldenhoff, G. Clayton, P. McDonough, supra note 80, p. 28.

${ }^{86}$ R. Marx, The Criteria of Applying the Internal Flight Alternative Test in National Refugee Status Determination Procedures, "International Journal of Refugee Law" 2002, vol. 14, issue $2 \& 3$, p. 182. 
asylum seekers should not be required to demonstrate that they have exhausted all the possibilities of reaching safety in an area within their own country (...) before seeking international protection" ${ }^{\prime \prime}$.

G.S. Goodwin-Gill and J. McAdam correctly claim that in some cases it may be "impossible or impracticable for the asylum seeker to move internally, rather than to cross an international frontier" ${ }^{\prime \prime 8}$. K. Keith provides a striking example of persons who could safely stay in their country of origin only if they move to a remote desert or to the top of the mountain ${ }^{89}$. Other scholars underline that

"Because a state is presumed to be entitled to act throughout its territory, the IPA is 'not normally a relevant consideration' if there is a risk of being persecuted by a state actor. (...) Only where it is clear that the power of the state authority or agent is geographically limited or 'where the State itself only has control over certain parts of the country' can the IPA be considered in cases of state supported persecution. An IPA is more likely if the risk of persecution comes from a non-state actor." ${ }^{\prime 90}$.

The UNHCR specified that a returnee must be able to "lead a relatively normal life without facing undue hardship" ${ }^{\prime 11}$ in a part of the country to which s/he is to be returned. Thus, not only physical security has to be concerned, but also respect for the

"basic civil, political and socio-economic human rights of the individual (...) [need to be ensured]. Questions of an economic nature, such as access to suitable employment, are not strictly relevant to the availability of protection, although the inability to survive elsewhere in the country may be another compelling reason to grant international protection. Another consideration in assessing the qualification of 'reasonable' includes an evaluation of the

87 Parliamentary Assembly of the Council of Europe, Recommendation 1440 (2000) on Restrictions on asylum in the member states of the Council of Europe and the European Union, Text adopted by the Assembly on 25 January 2000 (3rd Sitting), point 6.5.3.3. This view was also expressed in: N. Kelley, supra note 78, p. 15.

${ }^{88}$ G.S. Goodwin-Gill, J. McAdam, supra note 21, p. 124.

${ }^{89}$ K. Keith, supra note 85, p. 439.

${ }^{90}$ L. Aldenhoff, G. Clayton, P. McDonough, supra note 80, p. 35.

${ }^{91}$ UNHCR, supra note 80, point 5(II)a. 
subjective circumstances surrounding the alleged persecution, such as the depth and quality of the fear itself." ${ }^{22}$.

Other factors can also be considered e.g. the asylum seeker's sex or family relations. Thus, a verification of the general situation in the country of origin as well as the personal circumstances of an asylum seeker is needed.

H. Storey concludes that asylum seekers should not be expected to demonstrate the unavailability of protection in the whole territory of their country of origin ${ }^{93}$. Supporters of that approach suggest that this obligation could overburden applicants ${ }^{94}$. L. Aldenhoff, G. Clayton, and P. McDonough go further and claim that "The state bears the burden of proving that a suitable IPA exists." ${ }^{15}$. All of the above-cited scholars agree that an asylum seeker can be asked to demonstrate the unavailability of the protection in other parts of the country only after receiving a notice from a status determination authority about an intended application of an $\mathrm{IPA}^{96}$. However, it should be uncontested that an ex nunc assessment of the situation in the part of the country of origin should always take place.

Additional guidelines on an application of an IPA can be found in the ECHR judgment of 11 January 2007 in Salah Skeekh $v$. The Netherlands ${ }^{97}$. The Court specified that this concept may be applied if a person who is to be expelled will be able:

- to travel to the area concerned;

- to gain admittance to this area; and

- to settle there ${ }^{98}$.

92 UNHCR, An Overview of Protection Issues in. Western Europe: Legislative Positions Taken by UNHCR, European Series 1995, vol. 1, no. 3, Geneva September 1995, available at: http://www.unhcr.org/publications/euroseries/46e65e1e2/overview-protection-issueseurope-legislative-trends-positions-taken-unhcr.html [last accessed on: 8.10.2017], pp. 6465. More on this issue in: N. Kelley, supra note 78, p. 24 and L. Aldenhoff, G. Clayton, P. McDonough, supra note 80 , pp. 30-31.

${ }_{93}$ H. Storey, supra note 24, pp. 507-509.

94 Ibid., pp. 507-509; R. Marx, supra note 86, p. 183.

${ }_{95}$ L. Aldenhoff, G. Clayton, P. McDonough, supra note 80, p. 36.

${ }^{6}$ Ibid., pp. 36-37.

97 Appl. no. 1948/04.

${ }_{98}$ Ibid., para. 141. More in: E. Mak, The Sheltering Sky of Strasbourg; On the ECtHR's judgment in the case of Salah Sheekh v.the Netherlands and its effects on asylum policy and judication in the Netherlands, "Europe \& Law" 2007, no. 1, pp. 69-81. 
This reasoning can also be traced in EU law. Article 8(3) of Directive 2004/83/EC of 29 April 2004 on minimum standards for the qualification and status of third country nationals or stateless persons as refugees or as persons who otherwise need international protection and the content of the protection granted ${ }^{99}$ provided the possibility of applying an IPA, notwithstanding technical obstacles to return to the country of origin. This possibility was removed from Directive 2011/95/EU of the European Parliament and of the Council of 13 December 2011 on standards for the qualification of third-country nationals or stateless persons as beneficiaries of international protection, for a uniform status for refugees, or for persons eligible for subsidiary protection, and for the content of the protection granted (recast). Thus, the Directive envisages a need to ensure that a return is safe and legally available, which reflects the Salah Skeekh case ${ }^{100}$.

However, during the negotiations of Directive 2004/83/EC the EU Member States rejected the Commission's proposal to ensure that a person to be returned "has access to protection against persecution or serious harm (...) in a part of a country of origin". The same proposal was tabled again by the Commission when a draft of the recast of that Directive was negotiated. Nevertheless, as that draft was questioned by some EU Member States, Directive 2011/95/EU was adopted in a wording suggested by the Presidency. Therefore, some scholars claim that protection level has not increased ${ }^{101}$.

Nevertheless, the adopted text envisaged an obligation to take into account the general situation in the country and personal circumstances of an applicant. As regards the latter, some scholars claim that the intention was to put the burden of proof on asylum applicants, although this is not clearly stated in the Directive ${ }^{102}$. If that were the case, applicants could be overburdened, as has already been discussed above.

The Directive contains a need to ensure that the person to be expelled must be reasonably expected to settle in the country of return. However,

${ }^{99}$ OJ EU L 304 of 30.9.2004, pp. 12-23.

100 More in: H. Battjes, supra note 33, p. 210.

101 H. Battjes, supra note 33, p. 211.

102 Ibid., p. 212. 
as the text does not define what constitutes a "reasonable" expectation" ${ }^{103}$, it does not guarantee that the status determination authority will consider the availability of basic social and economic rights in the country of origin. Thus, the already cited UNHCR's suggestion that a returnee must be able to "lead a relatively normal life without facing undue hardship"104 is not explicitly reflected to in EU law. Nevertheless, it was observed that this notion is applied by the EU Member States in their practice ${ }^{105}$.

Finally, the Directive does not specify when a well-founded fear of persecution should be verified - is that obligation imposed before or after checking the availability of an IPA ${ }^{106}$. Therefore, different practices in that regard were noticed in the EU Member States ${ }^{107}$. Recalling that the second stage of development of a Common European Asylum System intended to "provide for a single, common procedure for reasons of efficiency, speed, quality, and fairness of the decisions"108, the wide discretion left to the EU Member States in that regard may be questioned.

In the S.K. case, the ECtHR did not call into question the legality of an IPA. What is more, it followed the already cited judgment of 28 June 2011 in Sufi and Elmi v. the United Kingdom ${ }^{109}$ and confirmed that a government has a right to maintain that an applicant would be safe and would not be exposed to a risk of ill-treatment upon transit and arriving in his/her home town or settling in another part of the country of return ${ }^{110}$.

In the S.K. case the Court was not provided with any well-justified evidence confirming that an individual assessment of possible illtreatment was carried out by the Russian authorities. Thus, the Strasbourg judges were not convinced that "the situation in Damascus is sufficiently safe for the applicant, who alleges that he would be drafted into active

\footnotetext{
${ }^{103}$ L. Aldenhoff, G. Clayton, P. McDonough, supra note 80, p. 37.

${ }^{104}$ UNHCR, supra note 80, point 5(II)a.

105 L. Aldenhoff, G. Clayton, P. McDonough, supra note 80, pp. 60-63.

${ }^{106}$ Ibid., p. 28.

107 Ibid., p. 68.

${ }^{108}$ European Commission, Communication from the Commission to the European Parliament, the Council, the European Economic and Social Committee and the Committee of Regions - Policy plan on asylum - An integrated approach to protection across the EU, COM(2008) 360 final, Brussels 17.6.2008, point 2.

109 In particular par. 267 of that judgment.

110 S.K., par. 62.
} 
military service, or that the applicant could travel from Damascus to a safe area in Syria"111. Therefore, the Court remained consistent with its L.M. judgment as regards the situation in Syria. In that way, the judgment is in line with the views of the EU as they have been set out in Directive 2011/95/EU. As the general situation in Syria was not considered safe enough, the Court did not verify if S.K. could "lead a relatively normal life without facing undue hardship" after return.

Taking the above into account (both - the issue of a risk/refugees sur place as well as an IPA), the Court concluded that the applicant's removal to Syria would violate Articles 2 and 3 of the Convention ${ }^{112}$.

\section{DETENTION WITHOUT LIKELY PROSPECTS FOR REMOVAL}

In the S.K. case, the applicant claimed that, even though his detention continued, he could not ask a national court to review the decision on his custody. The government responded that they had to prolong the detention, because S.K. submitted an application for temporary asylum. On that basis, authorities claimed that a return procedure was carried out with special diligence and the prolongation of the detention was a result of the applicant's actions.

The ECtHR rejected the government's view. The Court underlined that the applicant was not questioning his detention aiming at execution of his forcible administrative removal, but he was referring to his inability to obtain a judicial review of his detention after a certain lapse of time.

Russian law provided a possibility to ask for a reconsideration of a decision on imposing an administrative fine. As a result, a migrant could be released from detention, if a decision ordering an administrative removal was made void. Thus, a sanction could be lifted as a consequence of changes to a decision imposing a return order and - securing an execution of that order - a sanction (administrative detention). However, the sanction per se (detention) could not be questioned under Russian

111 Ibid. The name of the specific part of the country to which a return is expected to take place should be clearly indicated in the decision. More in: L. Aldenhoff, G. Clayton, P. McDonough, supra note 80, p. 58.

112 S.K., par. 63. 
law. Therefore, during custody, immigrants could not expect a release nor could they be ordered any alternatives to detention.

S.K. was not convicted of any criminal offence and his illegal stay in Russia was the only reason for his administrative removal ${ }^{113}$. The government did not claim that the applicant's presence in Russia would constitute a threat to public security or public health. This, again, reconfirms that securing an execution of an administrative return decision was the only reason for putting the applicant in custody ${ }^{114}$.

The ECtHR considered that S.K. was kept in detention, although his return was unlikely "due to the worsening situation in Syria"115. Therefore, the idea that "States [must] demonstrate that deportation must be a realistic prospect"116 was confirmed also in this case. As in the ECtHR judgment of 19 February 2009 in A v. the United Kingdom ${ }^{117}$, it thus rejected the view that detention was justified because of keeping the possibility of removal "under active review"118.

Therefore, the authorities should have considered imposing alternatives to detention in the applicant's case. However, as a decision on the applicant's detention could not be reassessed, the situation of S.K. was similar to the one described in the judgment of 17 July 2014 in Kim v. Russia"119. Thus, the Court underlined that it "previously found violations of Article $5 \S 1$ of the Convention on account of the same statutory framework for detention of foreigners with a view to

113 The fact that S.K. was already present in Russian territory differentiates the facts of this case from those of Saadi v. the United Kingdom (judgment of 29.1.2008, appl. no. 13229/03) where the application was submitted at the border and the applicant was detained.

114 As S.K. was asking for asylum it should be recalled that in principle the detention of persons applying for refugee status should be used exceptionally. See: Directive 2013/32/ EU, supra note 68 and UNHCR Executive Committee Conclusion no. 44 (1986), Report of the 37th Session, UN doc. A/ AC.96/688, par. 128. More in: G.S. Goodwin-Gill, J. McAdam, supra note 21 , pp. 462-465.

115 S.K., par. 115. This view is alike the one in L.M., par. 148.

116 C. Costello, supra note 27, p. 291.

117 Appl. no. 3455/05.

118 Ibid., par. 167. See: M. Milanovic, European Court decides A and others v. United Kingdom, EJIL Talk! of 19 February 2009, available at: https:/ / www.ejiltalk.org/ europeancourt-decides-a-and-others-v-united-kingdom/ [last accessed: 18.7.2017].

119 Appl. no. 44260/13, par. 148. 
administrative removal (...) [and therefore it] finds no sufficient reason to reach a different conclusion in the present case." ${ }^{120}$.

This reasoning can also be traced in EU law ${ }^{121}$. In the Kadzoev case ${ }^{122,}$ the CJEU made it clear that detention for the purpose of removal and detention for ensuring asylum procedure "fall under different legal rules" $^{\prime 123}$. In its later judgment in the Arslan case ${ }^{124}$, it specified that when a person applies for asylum, Directive 2008/115/EC does not apply.

Moreover, Directive 2013/32/EU clearly states that as a rule, persons applying for international protection should not be detained. Nevertheless, during negotiations, EU Member States added to the Commission a proposal ${ }^{125}$ that a person may be detained if a return procedure is carried out against that person ${ }^{126}$.

Even though it does not apply to asylum seekers, but to illegally resident immigrants, Article 15(4) of Directive 2008/115/EC of the European Parliament and of the Council of 16 December 2008 on common standards and procedures in Member States for returning illegally staying third-country nationals ${ }^{127}$ should also be mentioned. It explicitly states that when it appears that a reasonable prospect of removal no longer exists, detention ceases to be justified and the person concerned must be released immediately. The same applies when there is no longer a risk of absconding or of avoiding or hampering the preparations for return. In every case, detention shall be reviewed at reasonable intervals of time, either on application by the third-country national concerned or ex officio.

120 S.K., par. 116.

${ }^{121}$ Directive 2013/32/EU, supra note 68.

122 Said Shamilovich Kadzoev (Huchbarov), case C-357/09 PPU, judgment of 30.11.2009, ECLI:EU:C:2009:741.

${ }^{123}$ Compare with: E. Tsourdi, EU Reception Conditions: A Dignified Standard of Living for Asylum Seekers? [in:] V. Chetail, P. De Bruycker, M. Francesco, Reforming the common European asylum system: the new European Refugee law, Leiden 20167, p. 290.

${ }^{124}$ Mehmet Arslan v. Policie ČR, Krajské ředitelství policie Ústeckého kraje, odbor cizinecké policie, case C-534/11, judgment of 30.5.2013, ECLI:EU:C:2013:343.

125 European Commission, Amended proposal for a DIRECTIVE OF THE EUROPEAN PARLIAMENT AND OF THE COUNCIL on common procedures for granting and withdrawing international protection status (Recast), COM/2011/0319 final - COD 2009/0165, Brussels, 1.6.2011.

126 E. Tsourdi, supra note 123, p. 289.

${ }^{127}$ OJ L EU 348 of 24.12.2008, pp. 98-107. 
In the case of prolonged detention periods, reviews shall be subject to the supervision of a judicial authority.

Taking the above-cited regulations into account, it can be said that the EU law is coherent with guarantees which were referred to by the ECtHR in the S.K. judgment.

\section{ANON-PILOT JUDGMENT}

The already quoted text, namely that "the Court finds no sufficient reason to reach a different conclusion in the present case" ${ }^{128}$, may seem as an expression of an annoyance of the judges. This would not be surprising as the ECtHR repetitively finds that Russia violates Article $5 \S 1$ of the Convention. Nevertheless, in the S.K. the Court did not used a pilot judgment option. The Strasbourg judges also decided not to make a quasipilot judgment, which (according to M. Lubiszewski and J. Czepek ${ }^{129}$ ) is a less-intrusive interference into a national legal system. This policy is therefore non-coherent with the one applied in the recent Novruk v. Russia ${ }^{130}$ case.

In the S.K. case, the Russian authorities have not executed the judgments of L.M. and of Kim. Especially, the later decision is important in the S.K. case. This is due to the fact that Kim was a pilot judgment in which the Court found a violation of Article $5 \S 1$ of the 1950 Convention

128 S.K., par. 116.

${ }^{129}$ M. Lubiszewski, J. Czepek, Procedura wyroku pilotażowego w praktyce Europejskiego Trybunatu Praw Człowieka [A Pilot Judgment Procedure in Practice of the European Court of Human Rights], Warszawa 2016, p. 140. Compare with: B. Gronowska, Europejski Trybunat Praw Człowieka. W poszukiwaniu efektywnej ochrony praw jednostki [The European Court of Human Rights. Searching an Effective Defeat of the Rights of an Individual], Torun 2011, p. 77.

130 Appl. nos. 31039/11, 48511/11, 76810/12, 14618/13 and 13817/14, par. 93. The case considered return decisions which were issued to HIV-positive immigrants who had been refused a residence permit in Russia. See: P. Sadowski, Odmowa udzielenia zezwolenia na pobyt cudzoziemcowi-nosicielowi wirusa HIV - glosa do wyroku Europejskiego Trybunatu Praw Człowieka z 15.03.2016 r. w sprawie Novruk i inni przeciwko Rosji (skargi nr 31039/11, 48511/11, 76810/12, 14618/13 i 13817/14) [Refusal of a residence permit for HIV-positive foreigners commentary on European Court of Human Rights judgment of 15 March 2016 in case Novruk and Others v. Russia (Applications nos. 31039/11, 48511/11, 76810/12, 14618/18 and 13817/14)], "Europejski Przegląd Sądowy" 2017, issue 6, pp. 44-47. 
on account of the unreasonable duration of the applicant's detention ${ }^{131}$. On the above-mentioned findings, the Strasbourg judges "that the respondent State envisage taking the necessary general measures to limit detention periods so that they remain connected to the ground of detention applicable in an immigration context"132.

In the L.M. case, the ECtHR limited itself to an indication of individual measures for the execution of those judgments. It can be asked whether the Court took into account that in the L.M. case a decision was made 15 months after Kim. However, 31 months passed from the Kim to the S.K. and in that time the Court found "in a number of cases" violations of Article $5 \S 1$ of the Convention. Thus, the existence of a certain problem, which caused in the past or may cause in the future similar applications ${ }^{133}$, can be said to be met in the S.K. case. Therefore, the Court's perspective and analysis of reasons for the non-implementation of Kim could be useful. It could especially help to understand why repetitive cases which were judged after the Kim case have not resulted in another pilot judgment. Unfortunately, without these guidelines from Strasbourg, we can make only a more or less accurate supposition in that regard.

Firstly, it can be asked whether the Court considered the efficiency of the protection of the human rights of foreigners staying in Russia. An insufficient level of protection could justify the reluctance of the ECtHR to issue a pilot judgment - this careful approach provides asylum seekers, who are under Russian jurisdiction, with a possibility of seeking a remedy in Strasbourg only if they have exhausted domestic remedies. That supposition is based on the Russian government's unwillingness to amend national legislation if the Court's decision is considered to be against Russian interests ${ }^{134}$.

Secondly, according to M.A. Nowicki the Strasbourg Tribunal is still rather reluctantly using pilot judgment procedure - in 2011 there were

131 Kim, par. 72.

132 Ibid.

${ }^{133}$ More on those tests in: L.R. Glas, The Functioning of the Pilot-Judgment Procedure of the European Court of Human Rights in Practice, Netherlands Quarterly of Human Rights 2016, vol. 34, issue 1, pp. 41-70.

${ }^{134}$ Like in Alekseyev v. Russia, judgment of 21.10.2010, appl. nos. 4916/07, 25924/08 and 14599/09 or in Novruk case. See comments to the latter case in: P. Sadowski, supra note 130, pp. 44-37. 
just 5 judgments of this type (and some quasi-pilot ones) ${ }^{135}$. Nevertheless, it seems that this trend is changing. Especially "since Protocol no. 14 to the Convention entered into force, the Court has taken on a more proactive role in this process, by handing down an increasing number of pilot judgments or 'quasi-pilot judgments'; however, this practice has also been called into question by some of the Court's judges, the $\mathrm{CDDH}$, and certain legal experts" ${ }^{\prime 136}$.

\section{CONCLUSIONS}

The judgment in the S.K. v. Russia case comes at a very timely moment. The ECtHR correctly referred to the present situation in Syria and reiterated the rules governing the application of the concept of a risk/refugee sur place. In that context, an evaluation of a general risk of ill-treatment is particularly valuable.

Although the Court did not consider in detail an application of the tests which are applied in a context of an IPA, the judgment contains an important reflection on the "continuing hostilities in Syria (...) as well as on account of the possibility that he [the applicant] would be drafted into active military service, thus intensifying the risks to his life and $\operatorname{limb} b^{\prime \prime 137}$. The Court underlined the need to take into account the most recent information on the situation in the country of return and it recalled that it can act pro motu in that regard ${ }^{138}$. It also stressed that it is the responsibility of a government to provide a well-grounded and individualized justification for the possibility of applying an IPA ${ }^{139}$.

Finally, the general situation of indiscriminate violence in Syria was used by the ECtHRs to decide that the detention of S.K. was carried out

135 M.A. Nowicki, Wokót Konwencji Europejskiej. Komentarz do Europejskiej Konwencji Praw Człowieka [The European Convention. Commentary to the European Convention on Human Rights], 6 ed., Warszawa 2013, p. 231.

${ }^{136}$ Explanatory memorandum by M. Mr Pierre-Yves Le Borgn', rapporteur [in:] Committee on Legal Affairs and Human Rights, Implementation of judgments of the European Court of Human Rights: 9th report, par. 50.

\footnotetext{
137 S.K., par. 57.

138 Ibid., par. 60.

139 Ibid., par. 62.
} 
without realistic prospects of the applicant's removal. In that regard the Court referred to "the worsening situation in Syria"140. The Strasbourg judges underlined that in that case, the authorities should consider imposing alternatives to detention. Moreover, the Court reiterated that in all the cases involving detention there is a need to ensure that a detainee has the possibility of asking for a reconsideration of a decision on his/ her detention.

Taking the above into account, the judgment refers to essential guarantees, which have to be ensured in a refugee status determination procedure. It reconfirms obligations which were put on the Council of Europe. Thus, it is welcomed that the Court tried to justify it well. Therefore, it should be appreciated that in the S.K. the ECtHR:

- remained consistent with the judgment of 15 October 2015 in L.M. and Others v. Russia as regards returns to Syria,

- reiterated the 17 July 2008 decision in N.A. v. the United Kingdom ${ }^{141}$ on evaluation of a real risk of ill-treatment in return cases and

- reiterated its findings from the 17 July 2014 judgment in Kim v. Russia on the possibility of reviewing a decision on the detention of a migrant, and opted for application of alternatives to detention when a return is unlikely.

${ }^{140}$ Ibid., par. 115. This view is similar to the one in L.M., par. 148.

${ }^{141}$ Appl. no. 25904/07. 
